\title{
AC 2007-1426: DEVELOPING AND ALIGNING ENGINEERING ELEMENTS IN AN ELEMENTARY SCHOOL'S INTEGRATED ENGINEERING CURRICULUM
}

\author{
Robin Little, Douglas L. Jamerson Jr. Elementary School \\ ROBIN LITTLE is the Engineering Coach at Douglas L. Jamerson, Jr. Elementary School Center \\ for Mathematics and Engineering. She earned a B.A. in Elementary Education and a M.Ed. in \\ Educational Leadership from the University of South Florida. Her experiences include over 23 \\ years in early childhood classrooms and seven years as a teacher resource and trainer. Robin has \\ curriculum writing experience, including a nationally published teacher resource book integrating \\ science and literature with other areas of the curriculum.
}

\section{Charles Parsons, Douglas L. Jamerson, Jr. Elementary School}

CHARLES PARSONS is the Science Coach at Douglas L. Jamerson, Jr. Elementary School Center for Mathematics and Engineering. He earned a B.A. in Elementary Education from the University of South Florida. His experiences include over 30 years teaching in Kindergarten through fifth grade classrooms and $1 \frac{1}{2}$ years as a resource teacher. Chuck has curriculum writing experience and has presented at various state and national venues.

\section{Pat Van Driessche, Douglas L. Jamerson, Jr. Elementary School}

PAT VAN DRIESSCHE is a fourth grade teacher at Douglas L. Jamerson, Jr. Elementary School Center for Mathematics and Engineering. She earned a B.S. in Elementary Education from the University of Wisconsin-Superior and her M.S. in Specific Learning and Behavior Problems from the College of St. Thomas, St. Paul, MN. Her teaching experiences include over 30 years teaching first through sixth grade and seven years in exceptional student education. Pat has presented various district trainings and is currently involved in the development of the integrated curriculum at Jamerson.

\section{Kim Parsons, Douglas L. Jamerson, Jr. Elementary School}

KIM PARSONS is the Reading Coach for Kindergarten through Third grade at Douglas L. Jamerson, Jr. Elementary School Center for Mathematics and Engineering. She earned a B.A. in Elementary Education from Florida Atlantic University and a Master of Arts in Education from the University of South Florida. Prior to her position as Reading Coach, Kim's experience included fifteen years as a classroom teacher in grades one through five. Kim has presented at various county and state venues.

\section{Marilyn Barger, University of South Florida}

MARILYN BARGER is the Executive Director of FL-ATE, the Florida Regional Center for Manufacturing Education housed at Hillsborough Community College. She earned a B.A. in Chemistry at Agnes Scott College, and both a B.S. in Engineering Science and a Ph.D. in Civil Engineering from the University of South Florida. She has over 16 years of experience in developing curriculum in engineering and engineering technology and is a registered professional engineer in the State of Florida. She is currently working with Douglas L. Jamerson, Jr.

Elementary School to develop curriculum content for its Center for Mathmatics and Engineering.

\section{Richard Gilbert, University of South Florida}

RICHARD GILBERT is a professor of Chemical Engineering in the College of Engineering at the University of South Florida. He has developed educational materials for ISA (Instrument Society of America), AVS (American Vacuum Society) Science Educator's Workshop, and the National Science Foundation through a grant to develop high school science and math curriculum content. He is currently working with Douglas L. Jamerson, Jr. Elementary School to develop curriculum content for its Center for Math and Engineering. 
Debbie O'Hare, Douglas L. Jamerson Jr. Elementary School

DEBORAH O'HARE is a 4th and 5th grade teacher at Douglas L. Jamerson, Jr. Elementary School Center for Mathematics and Engineering. She earned a B.A. in Elementary Education from Florida State University and has National Board Certification. In 2006, she was one of the finalists for teacher of the year for her district. Her experiences include over 21 years as a classroom teacher in all grades. Her main focus has been in the intermediate grades. Presently, she "loops" with her class from 4th to 5th grade, thus keeping them for two years. Deborah has experience writing curriculum using the Backwards Design Process and has worked with the state to create, revise and edit the math questions used on the statewide test for fifth grade. 


\section{Developing and Aligning Engineering Elements in an Elementary School's Integrated Engineering Curriculum}

\section{Background}

Douglas L. Jamerson, Jr. Elementary School was built in 2003 in a predominantly ethnically isolated inner city neighborhood. Its location facilitated ethnicity integration without the aid of a district assigned plan. During its first year of operation, the school applied for and received a three year grant from the Magnet Schools Assistance Program (MSAP) that provided additional resources to support its curriculum and faculty development. The school has a K-5 student population with no special enrolment criteria and definitely functions as a typical neighborhood school. It has more than 600 students and at least 3 classrooms at each grade level. Student talents and abilities are normally distributed and there is no grouping of mainstream students by sections, test scores, and/or perceived ability. Every teacher at each grade level is expected to present the same curriculum and the topics and order of these presentations is driven by lesson plans that are horizontally and vertically integrated. A unique aspect of the curriculum and therefore a demand on its professional development plan is the fact that the school does not have a specific engineering instructional period but integrates the engineering content throughout the science, language arts, mathematics and physical education standards driven component of its educational mission. This approach forces each teacher to find ways to use these subjects to strengthen the understanding of the engineering topics being taught which then, in turn, enrich the student's core "reading, writing and arithmetic" learning experiences.

\section{Introduction}

"Though children do engage in a naïve engineering of sorts, it can be the case that they do not hear the word engineer except in connection with railroad locomotives and do not know that their playful activity can be a lifelong profession. Grown-up engineering, which is as old as civilization, maintains the youth and vigor and imagination of a child. This is why, when presented to children on their own terms, the excitement of engineering is immediately apparent and fully comprehendible. There is no child too young to play and therefore to engage in engineering..."1

At Douglas L. Jamerson, Jr. Elementary Center for Mathematics and Engineering, we, too, hold these beliefs as a strong foundation to building an integrated engineering curriculum at the elementary school level. However, like Henry Petroski, we also believe it is not only important to make children aware that what they are doing is engineering in its simplest form, but that exposing them to beginning engineering elements and explaining the "whys" of what they are doing is also vital. This is the premise upon which our journey began four years ago.

\section{Curriculum Development}

Being an inner city school with a mixed socioeconomic population of kindergartners through fifth grade students, the staff of Jamerson needed to make sure they provided a variety of 
developmentally appropriate activities to support the engineering concepts using readily available materials whenever possible. To accomplish this goal two engineering professors were recruited as advisors. We then collectively looked at Florida's Sunshine State Standards as the driving force of curriculum development. Current public policy demands that the curriculum of an elementary program meet all the educational expectations to produce students that can read, write, and do mathematics and science at the highest possible levels. In addition, these students must begin to develop deductive and inductive reasoning skills. They must learn to analyze, synthesize and evaluate data. Students must also learn social interactions to ultimately prepare themselves to become productive citizens. The challenge for Jamerson's Elementary engineering focused curriculum is to use engineering design and engineering science elements to facilitate accomplishing the school's primary mission as dictated by the benchmarks embedded within the Florida's Sunshine State Standards.

As we set out to design curriculum, we chose to use the Backwards Design Model ${ }^{2}$ as our model for our unit design plan. This model asks teachers to begin with the end in mind. Teachers develop their essential understandings and create the ending assessments before planning activities to reach their goals. Once this was accomplished, then the teachers could begin to design lessons that would support the outcomes desired. We chose to use the $5 \mathrm{Es} \mathrm{Model}^{3}$ for our lesson plan format since this had the elements of a highly effective lesson built into the design. The 5 Es include engage, explore, explain, extend, and evaluate. The combination of these models became our building tools of curriculum design.

The use of Science and Mathematics Standards as the foundational platform from which to build the engineering units represents a critical design criteria for our curriculum. Elementary science education is generally divided into three areas: physical science, earth science, and life science. These two operational components lead us to categorize the standards and the supporting engineering elements to be taught into seven units of study. They are as follows: Nature of Science and Engineering Interaction, Gravitational Force and Resultant Motion, Electromagnetic Force and Resultant Motion, Natural Resources, Space Exploration, Life Processes, and Ecosystems. We will take a closer look at each of these.

In Nature of Science and Engineering Interaction, the units generally focus on the importance of the role of engineering in society, the similarities and differences between scientists, inventors, and engineers, the tools and skills needed by these jobs, and a comparison and practical application of the scientific method and an engineering design process. This unit also stresses the importance of working collaboratively in teams. Students are provided with many opportunities to use the Jamerson Engineering Design Process (modified from Informed Design Process ${ }^{4}$ ) as well as the various tools and skills of engineers to solve challenging problems with specific design criteria.

In physical science, we have broken the standards into two units of study: Gravitational Force and Resultant Motion and Electromagnetic Force and Resultant Motion. The Gravitational Force and Resultant Motion units look at gravitational force, how and when it is applicable, what results occur from its application, how to calculate its strength and direction, and why engineers need to know this information in real world situations. Students engage in creating and applying gravitational force in various hands-on learning experiences. They collect their data, analyze it, 
and make redesign decisions accordingly. The content within the Electromagnetic Force and Resultant Motion units include the concept of waves, an in-depth study of the magnetic and electrostatic forces and force fields, and an introduction to electromagnetic force. Students explore how energy is stored, used, and calculated from these force fields, and what real world applications have been developed to solve societal problems. Some examples of engineering activities include primary students creating various kinds of waves and studying magnetic levitation while intermediate students use voltmeters and current meters to analyze application circuits or gather data to be able to calculate work and power.

Earth science standards are covered in another two units: Natural Resources and Space Exploration. These curriculum units allow teachers to connect the required learning elements associated with earth and atmospheric science to engineering tasked associated with these resources. How engineers either utilize natural resources and/or rearrange them to meet engineering objectives are common themes within these units. Resources are studied as to their sources (natural or man-made) as well as how and why they are used. Lessons range from how early Florida tribes created inland habitats and dugouts, in-depth study of landforms, weathering and erosion and how engineers work deal with such issues. The Space Exploration units not only deal with the ever popular outer space travel but exploration of our own earth and its vast expanse of areas. From the impact of sun, weather and man on rain forests or the early explorers' view of the world and/or the exploration of Mars and unknown planets, activities center on how engineers use data collection and ongoing knowledge to further develop the capabilities of understanding and manipulating the space we do or will inhabit.

The last area of elementary science education, life science, has also been developed into the two study units, Life Processes and Ecosystems, in our curriculum. Life Processes units deal not only with the foundational knowledge of plant and animal development, but look at how engineers have been able to aid or alter the natural development. Students become very aware of engineers' roles in finding better ways to help people, plants and animals meet their basic needs or developing better systems or tools to improve the quality of life. Ecosystems units involve how people, plants, and animals interact with their environment. In addition to learning the behaviors and habitats of animals, students will have opportunities to create representations of ideal habitats and biomes for complete food chains to be able to thrive.

While Science Standards provide the driving force, Math Standards are highly visible throughout the unit development. Although Jamerson teachers are required by the District to use Everyday Math $^{5}$ as their main math curriculum, teachers reinforce Math Standards every place possible in the engineering units. In the primary grades, where our main focus is to set images and ideas of engineering, teachers engage students in measurement, data collection and display, and introduce the structure of word problems using engineering examples. In the intermediate grade levels the quantitative nature of engineering is emphasized. Fourth graders are doing energy and power calculations and have also been introduced to vectors as engineering mathematical tools. The fifth grade students are increasing their skills in application of scalars. Force and free body diagrams are used as design tools for their bridge construction challenge and the study of stress, tension and other engineering parameters are embedded in their units of study. 


\section{Importance of Curriculum Alignment}

An important and unique characteristic of the curriculum at Douglas L. Jamerson, Jr. Elementary School is its horizontal and vertical integration and alignment. This combined alignment and integration permits the curriculum to mature as the school matures. This, in turn, drives student expectation levels up as the fraction of students in the higher grades increases to reflect more of our primary students moving through the school. The alignment quality also assures that we can increase our depth of focus with respect to engineering while the integration effort will strengthen the breath of our engineering curriculum. Both characteristics strengthen our faculty's commitment and investment in our school. The excitement of using engineering as a tool in all of our courses and the increased knowledge obtained during the process drive us to work together and do more.

\section{Integration and Horizontal Alignment}

Grade levels are at various stages of integrating and aligning their curriculum horizontally, depending on the strengths and knowledge base of their teachers. It takes a strong understanding of the Florida Sunshine State Standards, a familiarity with available teaching resources, an informed understanding of integration of subject areas, and a comfort level and understanding of the engineering elements to be taught in order for this to be truly successful. The goal at Jamerson is for all grade levels to not only integrate engineering concepts into their other subject areas, but to also build throughout the year on engineering elements previously taught in other units. We have recognized and celebrated all attempts by grade levels in this area and have accepted that it will be a continual process of change and development as the teachers get stronger in the prerequisite skills needed.

In sharing the following example, it should be known that this team has been together for all four years and are strong veteran teachers who keep themselves on the cutting edge of education by nature. The fourth grade teachers have the prerequisite skills needed and it is reflected in their curriculum development. Engineering ideas and elements are evident throughout their day in all subject areas. Their students use the Jamerson Engineering Design Process to guide them through a piece of writing from the inception of the idea through the various ways they choose to share their work. They solve social and behavior problems using the same steps of plan, design, check, and share. Everyday Math concepts are carried over and reinforced in engineering lessons. In many cases, students are stretched ahead to math skills that might be considered "beginning" in Everyday Math as teachers work on making them "developing" or "secured" through engineering activities. In reading, fiction and nonfiction books are used to connect engineering elements with reading skills. As an example during their Life Processes and Ecosystem units, students read the environmental mystery book entitled Missing Gator of Gumbo Limbo by Jean Craighead George to study human and animal behavior, various habitats, flow of pollution, and man's impact on the environment. They design water filtration systems, study native plants to learn how they could be used to lessen man's impact on the environment, and use technology to detect changes in water quality which might affect plants and animals. Social Studies concepts are reflected throughout the fourth grade units, helping to create the horizontal alignment of units. The State of Florida expects all fourth graders to learn about their state during their fourth grade year. This has been a thread that has been woven into all seven of 
the fourth grade engineering units. For example, during their Space Exploration unit, students study about early Florida explorers and their view of the world at the time. They learn about the ships the explorers sailed in and what tools they used for navigation. This allows them to use the concepts about properties of materials, tools, and the early scientists, inventors, or engineers that they learn about in their Nature of Science and Engineering Interaction unit. They review the concept of buoyant force and how it is calculated as they did during their Natural Resource unit. They also look at why the early explorers built their forts in areas abundant with natural resources. During the Space Exploration unit, students use the concepts they learned about forces to examine the structures of the forts that were built. They use books and the Internet to research various forts before they design forts of their own. Students study the native plants and the location of the Florida forts to see how these explorers impacted their environment or how the environment impacted them. Building upon previous concepts taught has been highly successful for these students.

\section{Vertical Alignment}

Realizing the importance of reinforcement of engineering elements over time, Jamerson staff put a plan in place for obtaining vertical alignment of units. Although every grade level was expected to develop engineering units in all seven areas, during the third year they were given leeway to decide on how they would go about teaching the standards included in each strand. They received guidance from the engineering professor advisors, but were allowed to determine which direction they wanted to head. In year four, vertical alignment of engineering elements between the grade levels was closely examined and adjustments made when needed. As the curriculum continues to be developed, this alignment will continually be refined. Vertical alignment of units has been recorded in matrixes for each grade level. (See Appendices A and B for kindergarten and fifth grade examples.)

An excerpt from the vertical alignment of science and engineering elements and supporting activities in the Gravitational Force and Resultant Motion unit is as follows:

\begin{tabular}{|l|l|l|}
\hline \multicolumn{2}{|c|}{ Gravitational Force and Resultant Motion Strand } \\
\hline Grade & \multicolumn{1}{|c|}{ Engineering Science Concepts } & \multicolumn{1}{c|}{ Examples } \\
\hline Kdgn & $\begin{array}{l}\text { Introduces forces as a push or pull through } \\
\text { fairy tales such as Goldilocks and the Three } \\
\text { Bears and Humpty Dumpty. }\end{array}$ & $\begin{array}{l}\text { Building chairs to support the mass of } 2 \\
\text { different Goldilocks dolls. } \\
\text { Finding ways to prevent Humpty from } \\
\text { falling off the wall, to protect his body, } \\
\text { and to protect his landing. }\end{array}$ \\
\hline $1^{\text {st }}$ & $\begin{array}{l}\text { Introduces work through the folk tale of } \\
\text { John Henry. }\end{array}$ & $\begin{array}{l}\text { Building puff "steam engines" } \\
\text { Building boats that float and can be } \\
\text { moved by forced air. }\end{array}$ \\
\hline $2^{\text {nd }}$ & $\begin{array}{l}\text { Introduces potential and kinetic energy as } \\
\text { well as friction. }\end{array}$ & $\begin{array}{l}\text { Building a lunch box with foods that } \\
\text { would provide energy for John Henry. }\end{array}$ \\
\hline $3^{\text {rd }}$ & $\begin{array}{l}\text { Introduces mechanical advantage of work } \\
\text { specific design criteria. }\end{array}$ \\
& $\begin{array}{l}\text { through simple machines as well as finding } \\
\text { mass in grams and weight in Newtons. }\end{array}$ & $\begin{array}{l}\text { Designing a pulley system with specific } \\
\text { mechanical advantage requirements. }\end{array}$ \\
\hline
\end{tabular}




\begin{tabular}{|l|l|ll|}
\hline $4^{\text {th }}$ & $\begin{array}{l}\text { Introduces calculations of volume, density, } \\
\text { buoyant force, power, and live load and } \\
\text { dead loads as well as the introduction of } \\
\text { free body diagrams and technical } \\
\text { drawings. }\end{array}$ & \begin{tabular}{l} 
- \\
- $\begin{array}{l}\text { Building and testing clay dugouts. } \\
\text { Calculating buoyant force and creating } \\
\text { free body diagrams. }\end{array}$ \\
- $\begin{array}{l}\text { Sketching technical drawing of a } \\
\text { K'Nex car. }\end{array}$ \\
\hline $5^{\text {th }}$
\end{tabular} & $\begin{array}{l}\text { Introduces various types of bridge designs, } \\
\text { Building K'Nex cars to test and } \\
\text { complete calculations. }\end{array}$ \\
& $\begin{array}{l}\text { various forces acting on a bridge (tension, } \\
\text { torsion, and compression) and how to } \\
\text { calculate their strength, distributive load, } \\
\text { state of failure or equilibrium. }\end{array}$ & $\begin{array}{l}\text { Calculating forces and showing applied } \\
\text { forces through free body diagrams. } \\
\text { Designing and building a model bridge } \\
\text { which will meet specific design criteria. } \\
\text { Completing a cost analysis of their } \\
\text { bridge design. }\end{array}$ \\
\hline
\end{tabular}

\section{Results}

The reinforcement of engineering elements throughout the year has resulted in high student engagement and increased knowledge of subject matter. Although individual unit assessments have been developed, their validity has not been verified at this time. Refinement of each instrument is underway. As far as concrete test scores, our first group of students who entered kindergarten are just now in third grade, which is where Florida begins formal testing known as Florida Comprehensive Assessment Test (FCAT). We have already seen a trend towards higher reading, writing, and math scores. FCAT Math composite scores have risen as you look at students who have been in the Math and Engineering program for third through fifth grades. When individual student scores are broken down, 59\% of our students are high performing, 67\% are making gains, and of our lowest $25 \%$ of students, $61 \%$ are also making gains. Science scores have not been disaggregated by student, as baseline data has just been established. But in the two years that the test has been given to fifth grade students the composite scores also show growth. 2007 will be the first year test scores will be broken down by student and school. We hope to be able to provide updated results at the time of our presentation.

\section{References}

${ }^{1}$ Petroski, H., (2003). “Early Education,” Children’s Engineering Convention, Virginia.

${ }^{2}$ Wiggins, G., \& McTighe, J., (1998). Understanding by Design. Alexandria, VA: Association for Supervision and Curriculum Development.

${ }^{3}$ Bybee, R. W. (1997). Achieving Scientific Literacy: From Purpose to Practice. Portsmith, NH. Heineman.

${ }^{4}$ Burghart, D. M. \& M. Hacker, (2003). New York State Curriculum for Advanced Technological Education.

${ }^{5}$ Bell, M., et al, (2002). Everyday Mathematics, The University of Chicago School Mathematics Project. Chicago, IL: SRA/McGraw-Hill. 


\begin{tabular}{|c|c|c|c|c|c|c|c|}
\hline \multicolumn{8}{|c|}{ Kindergarten Integrated Engineering Curriculum Units } \\
\hline & Engineering & \multicolumn{2}{|c|}{ Physical Science } & \multicolumn{2}{|c|}{ Earth Science } & \multicolumn{2}{|c|}{ Life Science } \\
\hline & $\begin{array}{c}\text { Nature of } \\
\text { Science and } \\
\text { Engineering } \\
\text { Interaction }\end{array}$ & $\begin{array}{c}\text { Gravitational } \\
\text { Force and } \\
\text { Resultant } \\
\text { Motion }\end{array}$ & \begin{tabular}{|c} 
Electromag- \\
netic Force \& \\
Resultant \\
Motion
\end{tabular} & $\begin{array}{l}\text { Natural } \\
\text { Resources }\end{array}$ & $\begin{array}{c}\text { Space } \\
\text { Exploration }\end{array}$ & $\begin{array}{c}\text { Life } \\
\text { Processes }\end{array}$ & Ecos \\
\hline 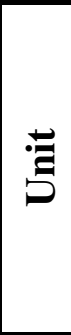 & $\begin{array}{l}\frac{\text { Scientists, }}{\text { Inventors, }} \\
\frac{\text { and }}{\underline{\text { Engineers }}}\end{array}$ & \begin{tabular}{|c}
$\frac{1 \text { Humpty }}{\text { Dumpty }}$ \\
$\frac{\underline{\text { Goldilocks \& 3 }}}{\text { Bears }}$ \\
$\frac{\text { 3 Billy Goats \& }}{\text { London Bridge }}$ \\
$\frac{\text { Jack \& Jill }}{\text { 3 Little Pigs }}$
\end{tabular} & $\frac{\text { Jack Be }}{\text { Nimble }}$ & $\frac{\frac{\text { Jack \& Jill }}{3 \text { Billy Goats }}}{\frac{\text { \& London }}{\text { Bridge }}}$ & $\mid$\begin{tabular}{||c|}
$\frac{3 \text { Little Pigs }}{\text { Animals as }}$ \\
$\frac{\text { Engineers }}{\text { Billy Goats }}$ \\
$\underline{\text { Jack \& Jill }}$
\end{tabular} & $\begin{array}{l}\text { Animals as } \\
\text { Engineers } \\
\end{array}$ & $\begin{array}{l}\frac{\text { Goldilocks }}{\text { \& 3 Bears }} \\
\underline{\text { Animals as }} \\
\underline{\text { Engineers }}\end{array}$ \\
\hline 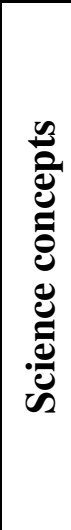 & \begin{tabular}{||l} 
scientific \\
processes, \\
including \\
observation \& \\
tools \\
- teamwork \\
- distinction \\
between \\
scientist, \\
inventor, \& \\
engineer
\end{tabular} & \begin{tabular}{|l} 
- \\
force as a \\
push and pull \\
- gravity \\
- safety \\
- properties of \\
materials
\end{tabular} & 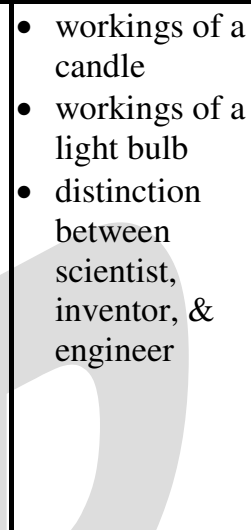 & \begin{tabular}{|l} 
- \\
nhat are \\
resources \\
- how are \\
natural \\
resources \\
used \\
- how natural \\
resources can \\
be conserved
\end{tabular} & \begin{tabular}{|l||} 
- forces of \\
weather \\
affecting \\
structures \\
- properties of \\
materials \\
- states of \\
matter \\
- effects of the \\
sun on \\
various \\
materials
\end{tabular} & 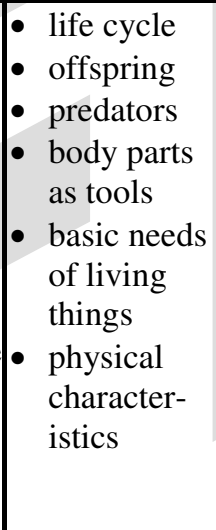 & \begin{tabular}{|l} 
people's \\
effects on \\
other's \\
environ- \\
ments \\
humans \\
encroaching \\
on animal's \\
environment \\
animals \\
interaction \\
with their \\
environment
\end{tabular} \\
\hline . & \begin{tabular}{|l} 
Jamerson \\
Design \\
Process
\end{tabular} & $\begin{array}{l}\text { - blueprints \& } \\
\text { footprints }\end{array}$ & $\begin{array}{l}\text { sources of } \\
\text { energy } \\
\text { changes in } \\
\text { lighting over } \\
\text { time } \\
\text { - Thomas } \\
\text { Edison and } \\
\text { his role }\end{array}$ & \begin{tabular}{|l} 
sources of \\
water over \\
time \\
- George \\
Washington \\
Carver \& \\
crop rotation
\end{tabular} & \begin{tabular}{|l|} 
- \\
blueprints \& \\
footprints
\end{tabular} & \begin{tabular}{|l} 
- nature's \\
engineers \\
- engineering \\
as a way to \\
make life \\
"easier" or \\
"better"
\end{tabular} & \begin{tabular}{|l} 
man's \\
impact on \\
animal's \\
habitat \\
animal / \\
ecosystem \\
response to \\
man's \\
impact \\
\end{tabular} \\
\hline 車 & $\begin{array}{l}\text { - } \text { measurement } \\
\text { - numbers and } \\
\text { scalars }\end{array}$ & - measurement & $\begin{array}{l}\text { qualitative } \\
\text { measurement } \\
\text { of light } \\
\text { intensity }\end{array}$ & \begin{tabular}{|l} 
ordinal \\
position \\
liquid \\
(volume) \\
measure- \\
ments \\
\end{tabular} & 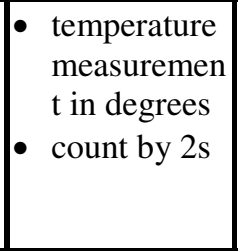 & $\begin{array}{l}\text { measure- } \\
\text { ment in } \\
\text { time }\end{array}$ & $\begin{array}{l}\text { counting } \\
\text { scalar } \\
\text { quantities } \\
\text { graphing } \\
\text { concepts }\end{array}$ \\
\hline
\end{tabular}

Units in red are primary introduction of concepts. Units in black are reinforcement of concepts.

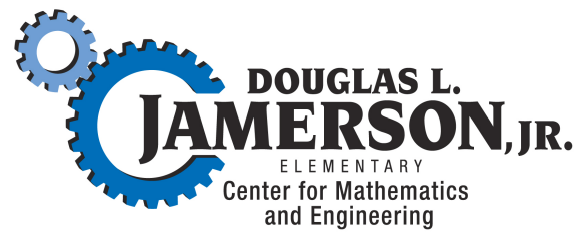




\begin{tabular}{|c|c|c|c|c|c|c|c|}
\hline \multicolumn{8}{|c|}{ Fifth Grade Integrated Engineering Curriculum Units } \\
\hline & Engineering & \multicolumn{2}{|c|}{ Physical Science } & \multicolumn{2}{|c|}{ Earth Science } & \multicolumn{2}{|c|}{ Life Science } \\
\hline & $\begin{array}{l}\text { Nature of } \\
\text { Science and } \\
\text { Engineering } \\
\text { Interaction }\end{array}$ & \begin{tabular}{|c|} 
Gravitational \\
Force and \\
Resultant \\
Motion
\end{tabular} & $\begin{array}{c}\text { Electromag- } \\
\text { netic Force \& } \\
\text { Resultant } \\
\text { Motion } \\
\end{array}$ & $\begin{array}{l}\text { Natural } \\
\text { Resources }\end{array}$ & $\begin{array}{c}\text { Space } \\
\text { Exploration }\end{array}$ & $\begin{array}{c}\text { Life } \\
\text { Processes }\end{array}$ & Ecosystems \\
\hline 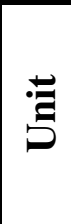 & 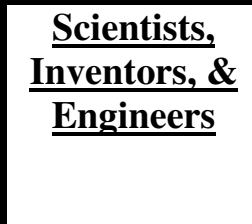 & Bridges & \begin{tabular}{|l}
$\frac{\text { Application of }}{\text { Magnetic and }}$ \\
$\frac{\text { Electro- }}{\text { magnetic }}$ \\
Force Fields
\end{tabular} & $\frac{\text { Conservation }}{\underline{\text { of Natural }}}$ & $\begin{array}{c}\text { Space } \\
\text { Engineering }\end{array}$ & $\frac{\frac{\text { Development }}{\text { of Plants and }}}{\underline{\text { Animals }}}$ & $\begin{array}{c}\text { Earth's } \\
\text { Environment }\end{array}$ \\
\hline 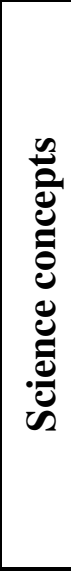 & $\begin{array}{ll}\text { - } & \text { scientific } \\
\text { processes } \\
\text { - } & \text { scientific } \\
\text { method }\end{array}$ & 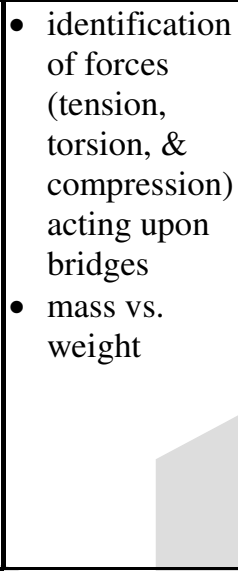 & \begin{tabular}{|l} 
- \\
identification \\
of forces / \\
fields \\
- simple and \\
parallel \\
circuits used \\
in creation of \\
telegraph \\
electro- \\
magnets
\end{tabular} & \begin{tabular}{|l} 
man, \\
erosion, \& \\
weathering's \\
effects on \\
natural \\
resources \\
- conservation
\end{tabular} & \begin{tabular}{|l} 
comparison \\
of earth to \\
fictional \\
planet / \\
moon \\
environ- \\
ment \\
history of \\
NASA \\
program \\
gravity / \\
force in \\
space / \\
planets
\end{tabular} & 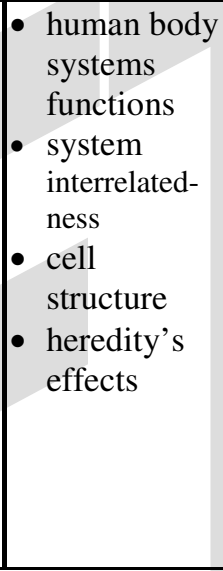 & $\begin{array}{l}\text { - character- } \\
\text { istics of } \\
\text { Earth's } \\
\text { environment }\end{array}$ \\
\hline 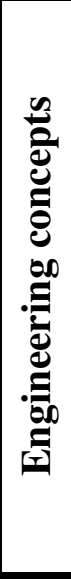 & $\begin{array}{ll}\text { - } & \text { applying } \\
\text { Jamerson } \\
\text { Design } \\
\text { Process } \\
\text { - different } \\
\text { engineering } \\
\text { fields }\end{array}$ & $\begin{array}{l}\text { - different type } \\
\text { of bridges \& } \\
\text { when they are } \\
\text { used } \\
\text { - calculating of } \\
\text { forces } \\
\text { - strategies to } \\
\text { create } \\
\text { equilibrium } \\
\text { - live \& dead } \\
\text { loads } \\
\text { - Roebling } \\
\text { family \& thei } \\
\text { contributions }\end{array}$ & \begin{tabular}{|l} 
measurement \\
of forces \\
important \\
people in \\
these fields \& \\
their \\
contributions \\
effects on \\
society \\
impact of \\
technology \\
on society \\
system losses
\end{tabular} & \begin{tabular}{|l} 
roles of \\
engineering \\
control for \\
man's use; \\
control to \\
protect man \\
impact on \\
society \\
controlling \\
beach \\
erosion \\
seawall \\
design
\end{tabular} & $\begin{array}{l}\text { impact of } \\
\text { NASA } \\
\text { engineering } \\
\text { on society } \\
\text { robotics for } \\
\text { manipulat- } \\
\text { ing } \\
\text { materials }\end{array}$ & 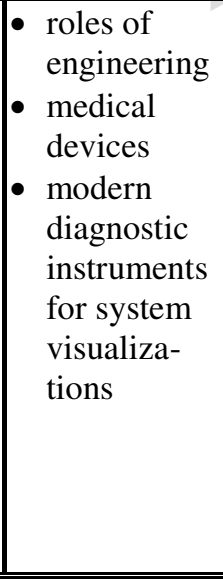 & $\begin{array}{l}\text { - impact of } \\
\text { engineering } \\
\text { recycling \& } \\
\text { reuse } \\
\text { current } \\
\text { negative } \\
\text { impacts and } \\
\text { solutions }\end{array}$ \\
\hline 造 & $\begin{array}{l}\text { - timeline of } \\
\text { scientific and } \\
\text { technological } \\
\text { advancements }\end{array}$ & $\begin{array}{l}\text { - } \text { multiplication } \\
\text { - } \text { measurement } \\
\text { - } \text { graphing }\end{array}$ & $\begin{array}{ll}\text { - } & \text { measurement } \\
\text { - } & \text { multiplication } \\
\end{array}$ & $\begin{array}{ll}\text { - } & \text { rate concepts } \\
\text { - } & \text { complex } \\
& \text { dimensions }\end{array}$ & 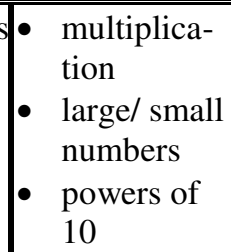 & - measure- & $\begin{array}{l}\text { - measurement } \\
\text { - recovery \%'s }\end{array}$ \\
\hline
\end{tabular}

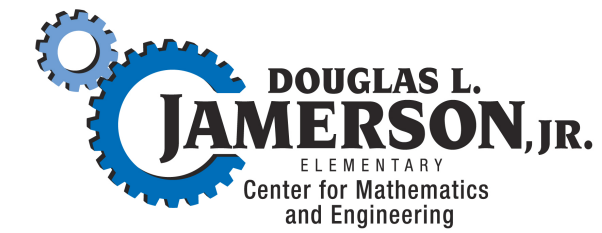

